\title{
A Polymorphism in the $\alpha 4$ Nicotinic Receptor Gene (Chrna4) Modulates Enhancement of Nicotinic Receptor Function by Ethanol
}

\author{
Christopher M. Butt, Scott R. Hutton, Jerry A. Stitzel, Seth A. Balogh, Jeremy C. Owens, and Allan C. Collins
}

\begin{abstract}
Background: Several studies indicate that ethanol enhances the activity of $\alpha 4 \beta 2$ nicotinic acetylcholine receptors (nAChR). Our laboratory has identified a polymorphism in the $\alpha 4$ gene that results in the substitution of an alanine (A) for threonine (T) at amino acid position 529 in the second intracellular loop of the $\alpha 4$ protein. Mouse strains expressing the A variant have, in general, greater nAChR-mediated ${ }^{86} \mathrm{Rb}^{+}$ efflux in response to nicotine than strains with the T variant. However, the possibility of the polymorphism modulating the effects of ethanol on the ${ }^{86} \mathrm{Rb}^{+}$efflux response has not been investigated.

Methods: We have used the ${ }^{86} \mathrm{Rb}^{+}$efflux method to study the acute effects of ethanol on the function of the $\alpha 4 \beta 2 \mathrm{nAChR}$ in the thalamus in six different mouse strains. Experiments were also performed on tissue samples taken from F2 intercross animals. The F2 animals were derived from A/J mice crossed with a substrain of $\mathrm{C} 57 \mathrm{BL} / 6 \mathrm{~J}$ mice that carried a null mutation for the gene encoding the $\beta 2 \mathrm{nAChR}$ subunit.

Results: In strains carrying the A polymorphism (A/J, AKR/J, C3H/Ibg), coapplication of ethanol $(10-100 \mathrm{mM})$ with nicotine $(0.03-300 \mu \mathrm{M})$ increased maximal ion flux when compared with nicotine alone with no effect on agonist potency. In contrast, ethanol had little effect on the nicotine concentrationresponse curve in tissue prepared from strains carrying the T polymorphism (Balb/Ibg, C57BL/6J, C58/J). Experiments with the F2 hybrids demonstrated that one copy of the A polymorphism was sufficient to produce a significant enhancement of $\mathrm{nAChR}$ function by ethanol $(50 \mathrm{mM})$ in animals that were also $\beta 2$ $+/+$. Ethanol had no effect on nicotine concentration-response curves in $\mathrm{T} / \mathrm{T} \beta 2+/+$ animals.

Conclusions: The results suggest that the A/T polymorphism influences the initial sensitivity of the $\alpha 4 \beta 2$ nAChR to ethanol.
\end{abstract}

Key Words: ${ }^{86} \mathrm{Rb}^{+}$Efflux, Nicotine, Genetic Predisposition.

$\mathbf{N}^{\mathrm{E}}$ EARLY ALL (70-90\%) alcoholics are heavy smokers. In contrast, $10 \%$ of individuals who do not abuse other drugs and are not mentally ill are smokers (Batel et al., 1995; Hughes, 1993). One possible reason for the high correlation between tobacco addiction and alcoholism may be a common substrate (Hettema et al., 1999; True et al., 1999). True et al. (1999) reported that a significant genetic correlation $(r=0.68)$ exists between these two forms of drug dependencies. Another study has reported an association between alcohol sensitivity and a marker on chromo-

From the Institute for Behavioral Genetics (CMB, SAB, JCO, ACC), University of Colorado, Boulder, CO; University of North Carolina Neuroscience Center (SRH), Chapel Hill, NC; and Department of Pharmacology (JAS), University of Michigan, Ann Arbor, MI.

Received for publication December 3, 2002; accepted March 3, 2003.

This work was supported by National Institute on Alcohol Abuse and Alcoholism Grants AA11156 (ACC), AA07464 (CMB), and AA13465 (CMB); a Research Scientist Award (DA00197; ACC); and a grant from the Alcoholic Beverage Medical Research Foundation (JAS).

Reprint requests: Allan C. Collins, Institute for Behavioral Genetics, University of Colorado, Boulder, Campus Box 447, Boulder, CO 80309-0447; E-mail: al.collins@colorado.edu

Copyright () 2003 by the Research Society on Alcoholism.

DOI: 10.1097/01.ALC.0000067973.41153.BC some 20 (D20S94) (Schuckit et al., 2001). The gene encoding the $\alpha 4$ subunit of neuronal nicotinic acetylcholine receptors (nAChR), CHRNA4, maps to the same region, as does D20S94, in humans (Bessis et al., 1990).

There is little doubt that the effects of nicotine are mediated by the nAChR. Molecular methods have identified nine $\alpha$ subunits $(\alpha 2-10)$ and three $\beta$ subunits $(\beta 2-4)$ that are expressed in the central nervous system (Deneris et al., 1988, 1989; Goldman et al., 1986; Le Novère et al., 1996; Marks et al., 1992; Wada et al., 1989). Null-mutant (gene knock-out) (Marubio et al., 1999; Picciotto et al., 1995; Ross et al., 2000) and immunologic studies (Flores et al., 1992) suggest that receptors that consist of $\alpha 4$ and $\beta 2$ subunits make up the majority of high-affinity $\left[{ }^{3} \mathrm{H}\right]$ nicotine binding sites in the brain, whereas the $(\alpha 7)_{5}$ homo-oligomer binds [ $\left.{ }^{125} \mathrm{I}\right] \alpha$-bungarotoxin (Orr-Urtreger et al., 1997). Together, these two binding sites constitute 70 to $80 \%$ of all neuronal nAChRs (Marks et al., 1992; Picciotto et al., 1995). Nearly all of the nAChRs in the thalamus, the brain region that we use for ${ }^{86} \mathrm{Rb}^{+}$efflux studies of $\mathrm{nAChR}$ function, are composed primarily of $\alpha 4$ and $\beta 2$ subunits (Marks et al., 1998, 1999; Zoli et al., 1998).

Many studies have demonstrated that ethanol alters the function of nAChRs expressed in the peripheral nervous 
system (Collins, 1996), but only a few have attempted to determine effects of ethanol on native nAChRs expressed in the brain. Coapplication of ethanol with nicotinic agonists directly enhances the function of what are likely to be $\alpha 4 \beta 2 \mathrm{nAChRs}$, as measured electrophysiologically in cultures of prenatal rat cerebral cortex (Aistrup et al., 1999; Marszalec et al., 1999). Similar experiments conducted on $\alpha 4 \beta 2$ nAChRs expressed in Xenopus oocytes also indicate that receptor function is enhanced by ethanol (10-100 mM) (Cardoso et al., 1999).

Studies done using mice also suggest that ethanol's effects may be mediated to some extent by genes that influence nicotine's effects. For instance, studies using mice selectively bred (LS and SS lines) for differences in duration of ethanol-induced loss of the righting reflex ("sleep time") have demonstrated that the alcohol-sensitive LS mice are more sensitive to acute injections of nicotine in several behavioral and physiologic measures than the alcohol-insensitive SS mice (de Fiebre and Collins, 1988, 1989, 1992; de Fiebre et al., 1987, 1991). More recent findings have associated several effects of ethanol with a region in mouse chromosome 2 that contains Chrna4, the gene that encodes the $\alpha 4 \mathrm{nAChR}$ subunit in this species. This chromosomal region has been linked not only to the effects of ethanol on acoustic startle and on Y-maze activity in recombinant inbred strains derived from the LS and SS mice (Owens et al., 2002; Tritto et al., 2001) but also to ethanol preference in recombinant inbred strains derived from a cross between $\mathrm{C} 57 \mathrm{BL} / 6 \mathrm{~J}$ and $\mathrm{A} / \mathrm{J}$ mice (Gill et al., 1998).

The finding that sensitivity to alcohol and nicotine cosegregate in animals derived from LS and SS mice led our laboratory to search for polymorphisms in the $\alpha 4$ subunit gene between these two mouse lines (Stitzel et al., 2000). A single nucleotide polymorphism that results in $\alpha 4$ subunit variants that possess either an alanine (A) or a threonine (T) at amino acid position 529 was found. This polymorphism is associated with differences in nAChR function (Dobelis et al., 2002) and is correlated across mouse strains with variability in several nicotine- (Stitzel et al., 2000; Tritto et al., 2002) and alcohol-related behaviors (Tritto and Dudek, 1994; Tritto et al., 2001). Here we report that the A/T polymorphism not only is associated with differences in nAChR function but also seems to determine whether the function of native nAChRs is enhanced by ethanol.

\section{METHODS}

\section{Mice}

Male and female mice from six inbred strains were used in these studies. The $\mathrm{C} 57 \mathrm{BL} / 6 \mathrm{~J}, \mathrm{C} 3 \mathrm{H} / \mathrm{Ibg}$, Balb/Ibg, and A/J strains were produced from breeder mice maintained at the Institute for Behavioral Genetics (IBG), University of Colorado (Boulder, CO). The Ibg strains have been maintained at IBG for $>20$ generations. The C58/J and AKR/J strains were purchased directly from Jackson Laboratories (Bar Harbor, ME). An F2 hybrid was also generated at IBG for this study (see details below).
All mice were weaned and separated by sex when they were 25 days old. They were then housed in groups of five to a cage and maintained on a 12-hr light/12-hr dark cycle (lights on 7 AM to 7 PM). All animals were given unlimited access to food (Teklad Rodent Diet) and water. Animals were 60 to 90 days old when used. All animal care and experimental procedures were approved by and performed in accordance with the guidelines of the Animal Care and Utilization Committee of the University of Colorado, Boulder.

\section{Development and Genotyping of F2 Animals}

The initial purpose of developing the F2 hybrid mouse strain used in this study was to observe the role of the $\mathrm{A} / \mathrm{T}$ polymorphism in behavioral responses to ethanol and nicotine. The results of the behavioral studies will be published elsewhere. Nevertheless, it was logical to test the correlation of the polymorphism with nAChR function (Dobelis et al., 2002) with the F2 hybrids because they were available to us. The F2 intercross was generated by crossing the $\mathrm{A} / \mathrm{J}$ strain with $\mathrm{C} 57 \mathrm{BL} / 6 \mathrm{~J}$ mice containing a null mutation ("knock-out") for the $\beta 2 \mathrm{nAChR}$ subunit gene, Chrnb2. The $\beta 2$ subunit gene deletion had been bred for eight generations onto the C57BL/6J background. Six different parental matings were used to produce the F1 animals. F1 animals from different families were then mated to produce the $\mathrm{F} 2$ progeny. Tail clippings $(\sim 1 \mathrm{~cm})$ were taken from each F2 animal for genotyping. DNA was extracted from the clippings with a Qiagen (Valencia, CA) DNEasy Tissue Kit. $\beta 2$ genotypes were determined by polymerase chain reaction with oligonucleotide probes specific for the Chrnb2 sequence. Chrna4 A/T genotype was determined by polymerase chain reaction amplification with oligonucleotide probes specific for a region of Chrna4 that flanks the A/T polymorphism followed by digestion with StuI (New England Biolabs, Beverly, MA) as described in Dobelis et al. (2002). The gene products were electrophoresed on $2.5 \%$ (Chrna4 products) or 1.5\% (Chrnb2 products) agarose gels and stained with ethidium bromide. Two independent observers then scored the genotypes.

\section{${ }^{86} \mathrm{Rb}{ }^{+}$Release}

The brain was removed from each mouse (60-90 days old; killed by cervical dislocation), and the thalamus was dissected. Crude synaptosomes were prepared from the thalamus by homogenization in 10 volumes of ice-cold $\left(4^{\circ} \mathrm{C}\right)$ Percoll medium I (sucrose, $320 \mathrm{mM}$; HEPES, $5 \mathrm{mM}$; $\mathrm{pH}$ 7.5) followed by centrifugation at $12,000 \times g$ for $20 \mathrm{~min}$. The resulting pellet was then resuspended in uptake buffer $(140 \mathrm{mM} \mathrm{NaCl}, 1.5 \mathrm{KCl} \mathrm{mM}$,

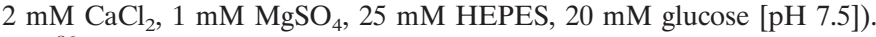
The ${ }^{86} \mathrm{Rb}^{+}$was loaded into the synaptosomes through a 20-min incubation $\left(25^{\circ} \mathrm{C}\right)$ in uptake buffer containing approximately $4 \mu \mathrm{Ci}$ of carrier-free ${ }^{86} \mathrm{RbCl}$ (Perkin-Elmer, Boston, MA). The loaded synaptosomes were then placed onto glass fiber filters by gentle vacuum $(-0.2$ atmospheres) followed by one $500-\mu l$ wash with uptake buffer. The samples were then placed on a perfusion apparatus and treated with perfusion buffer (135 $\mathrm{mM} \mathrm{NaCl}, 5 \mathrm{mM} \mathrm{CsCl}, 1.5 \mathrm{mM} \mathrm{KCl}, 2 \mathrm{mM} \mathrm{CaCl}_{2}, 1 \mathrm{mM} \mathrm{MgSO}_{4}, 25 \mathrm{mM}$ HEPES, $20 \mathrm{mM}$ glucose, $50 \mathrm{nM}$ tetrodotoxin [pH 7.5]) at a rate of 2.5 $\mathrm{ml} / \mathrm{min}$. Pooling of the buffer at the perfusion platform was prevented by actively removing the buffer with a second pump. The second pump was set at a rate of $3.2 \mathrm{ml} / \mathrm{min}$. The effluent was pumped through a $200-\mu \mathrm{l}$ flow-through Cherenkov cell in a $\beta$-RAM Radioactivity HPLC Detector (IN/US Systems, Inc.; Tampa, FL). The amount of radioactivity in the effluent was determined in 3 -sec fractions. Stimulation $(5 \mathrm{sec})$ of the synaptosomes was achieved by diverting the incoming perfusion buffer with a four-way rotary Teflon injection valve through a 200- $\mu$ l loop containing the test solution. Samples were stimulated with perfusion buffer solutions containing nicotine $(0.001-300 \mu \mathrm{M})$ or nicotine and ethanol $(10,30,50$, or $100 \mathrm{mM})$. Each sample was stimulated only once. Bovine serum albumin (BSA; Fraction V; $0.1 \%$ final concentration) was added to the perfusion buffer in some experiments. All materials were purchased from Sigma-Aldrich (St. Louis, MO) unless specified otherwise. 


\section{Data Analysis}

The amount of nicotine-stimulated ${ }^{86} \mathrm{Rb}^{+}$efflux was determined in 3 -sec intervals as the counts exceeding basal release during the time of exposure to the test solution. The data were normalized using an established method (Marks et al., 1996). In short, the stimulated release was divided by the baseline release. First, the baseline release over time was fit to a two-phase exponential decay curve. The stimulated release was then divided by the calculated baseline release during the time of stimulation. Thus, one response unit is twice basal release. The responses at each time interval of stimulation were then summed to yield the total response for a given test run. Dose-response curves were plotted and fit with the Michaelis-Menten equation, or two Michaelis-Menten equations using Graph Pad Prism 3.0 (GraphPad Software, San Diego, CA) or Sigma Plot 2001 (Jandel Scientific, San Raphael, CA). An F-test was used to determine which type of equation fit the data best. Significant differences $(p<0.05)$ between data sets were determined with two-tailed, unpaired $t$ tests. When $\mathrm{EC}_{50}$ values were compared, their log values were used. This was done because $\log \left(\mathrm{EC}_{50}\right)$ values are normally distributed but actual $\mathrm{EC}_{50}$ values are not (Hancock et al., 1988).

\section{RESULTS}

\section{Ethanol Enhances $n A C h R$ Function}

Figure 1 shows the overlay of typical ${ }^{86} \mathrm{Rb}^{+}$-efflux responses to nicotine $(30 \mu \mathrm{M})$ and nicotine $(30 \mu \mathrm{M})$ plus ethanol $(50 \mathrm{mM})$ using synaptosomes prepared from $\mathrm{C} 3 \mathrm{H} /$ Ibg mice. The two traces were obtained from synaptosomal samples taken from the same animal. The coapplication of ethanol with nicotine increased the amount of ${ }^{86} \mathrm{Rb}^{+}$flux through the nAChR when compared with the response to nicotine alone. Stimulating the synaptosomes with ethanol alone did not cause a detectable response and had no effect on baseline release (data not shown).

\section{$B S A$ and Ethanol Interactions}

When BSA was not present in the perfusion buffer, ethanol $(50 \mathrm{mM})$ produced a significant enhancement of ion flux in synaptosomes prepared from either $\mathrm{C} 3 \mathrm{H} / \mathrm{Ibg}$ or C57BL/6J strains (Fig. 2). The degree of ethanol enhancement was greater in the $\mathrm{C} 3 \mathrm{H} / \mathrm{Ibg}$ synaptosomes. When BSA $(0.1 \%)$ was present in the perfusion buffer, no effect of ethanol was seen. The addition of BSA resulted in an increase in control values of ion flux in both strains. The enhancement of $\mathrm{nAChR}$ function by BSA has been reported previously (Butt et al., 2002; Gurantz et al. 1993). Subsequent experiments were all performed in the absence of BSA.

\section{Strain Differences in Ethanol Enhancement}

Figure 3 illustrates the enhancement of $\mathrm{nAChR}$ function by coapplied ethanol across the entire nicotine concentration-response curve in $\mathrm{C} 3 \mathrm{H} / \mathrm{Ibg}$ mice. The degree of enhancement increased as higher ethanol concentrations were used. As demonstrated previously, the nAChR activation curve was biphasic (Butt et al., 2002; Marks et al., 1999). This was evidenced not only by the inflection of the concentration-response curve but also by the consistent

\section{$30 \mu \mathbf{M}$ Nicotine}

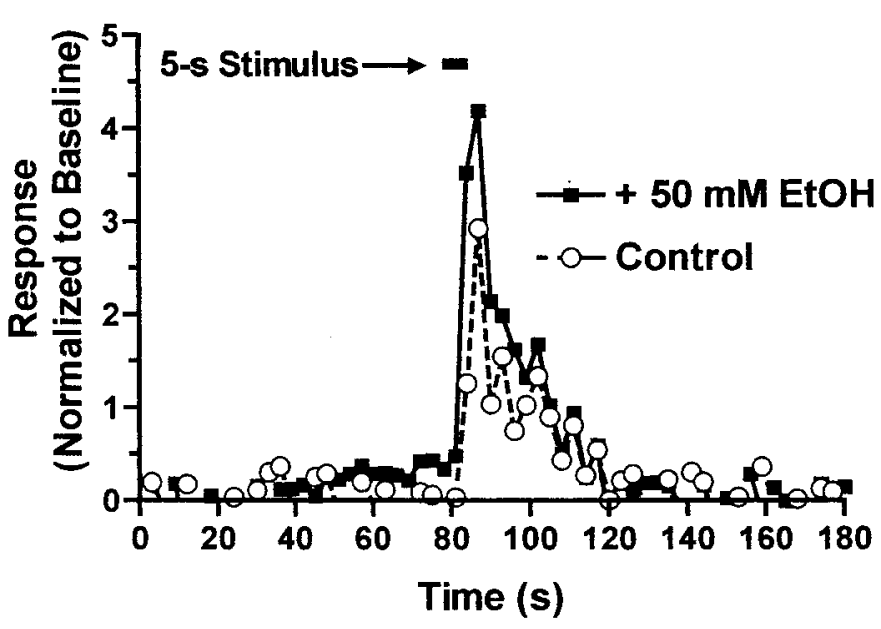

Fig. 1. Effect of coapplication of ethanol and nicotine on ${ }^{86} \mathrm{Rb}^{+}$efflux. These representative traces obtained from synaptosomes made from the same animal (C3H/lbg strain) show that a 5 -sec application of nicotine $(30 \mu \mathrm{M}$; $\bigcirc)$ produces a noticeably smaller response than when a 5-sec application of nicotine (30 $\mu \mathrm{M})$ plus ethanol $(50 \mathrm{mM}$; $)$ is used.

\section{$10 \mu \mathrm{M}$ Nicotine}

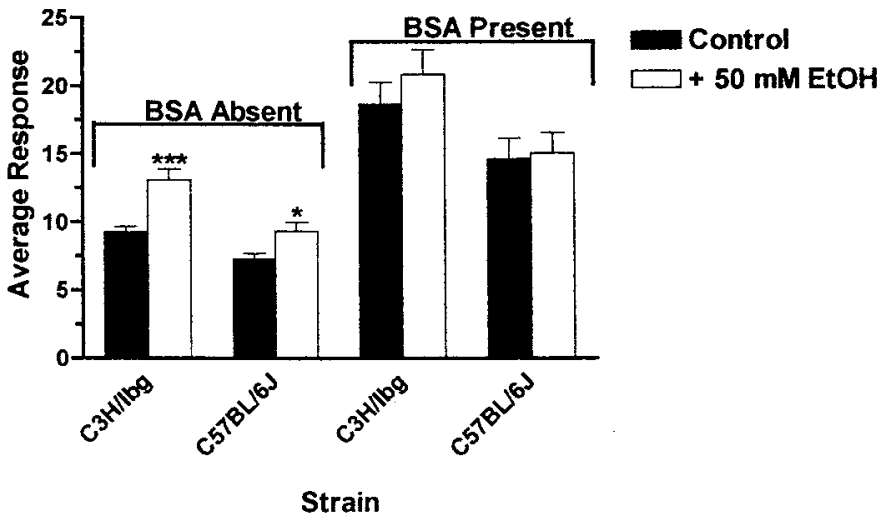

Fig. 2. BSA modulates ethanol's effects on ${ }^{86} \mathrm{Rb}^{+}$efflux. In the absence of BSA, coapplication of nicotine $(10 \mu \mathrm{M})$ with ethanol $(50 \mathrm{mM})$ significantly enhanced the response compared with nicotine-only controls. The presence of BSA abolished the enhancement of the response by ethanol. ${ }^{*} p<0.05$ or ${ }^{* * *} p<0.001$ when compared with control values in a two-tailed, unpaired $t$ test. Error bars represent the standard error of the mean ( \pm SEM); $N=4-9$.

finding that $>2 \log$ units of agonist concentration are required to produce maximal ion flux. In the absence of ethanol, the high-affinity phase of $\mathrm{nAChR}$ activation had an $\mathrm{EC}_{50}$ value $\left(\mathrm{EC}_{50 \mathrm{H}}\right)$ near $1 \mu \mathrm{M}$ and a maximal efflux $\left(\mathrm{V}_{\mathrm{H}}\right)$ of approximately 9 response units. The low-affinity phase had an $\mathrm{EC}_{50}\left(\mathrm{EC}_{50 \mathrm{~L}}\right)$ at $\sim 125 \mu \mathrm{M}$ and a maximal efflux of $\sim 4$ response units (Fig. 3A, Table 1). The lowest ethanol concentration (10 mM; Fig. 3A, Table 1) elicited some enhancement of receptor function. However, the only statistically significant effect that this concentration had was to decrease $\mathrm{V}_{\mathrm{H}}$. The higher ethanol concentrations used all significantly increased maximal ion flux $(30 \mathrm{mM}$ [Fig. 3B], 50 mM [Fig. 3C], 100 mM [Fig. 3D]). Fitting 


\section{$\mathrm{C} 3 \mathrm{H} / \mathrm{lbg}$}
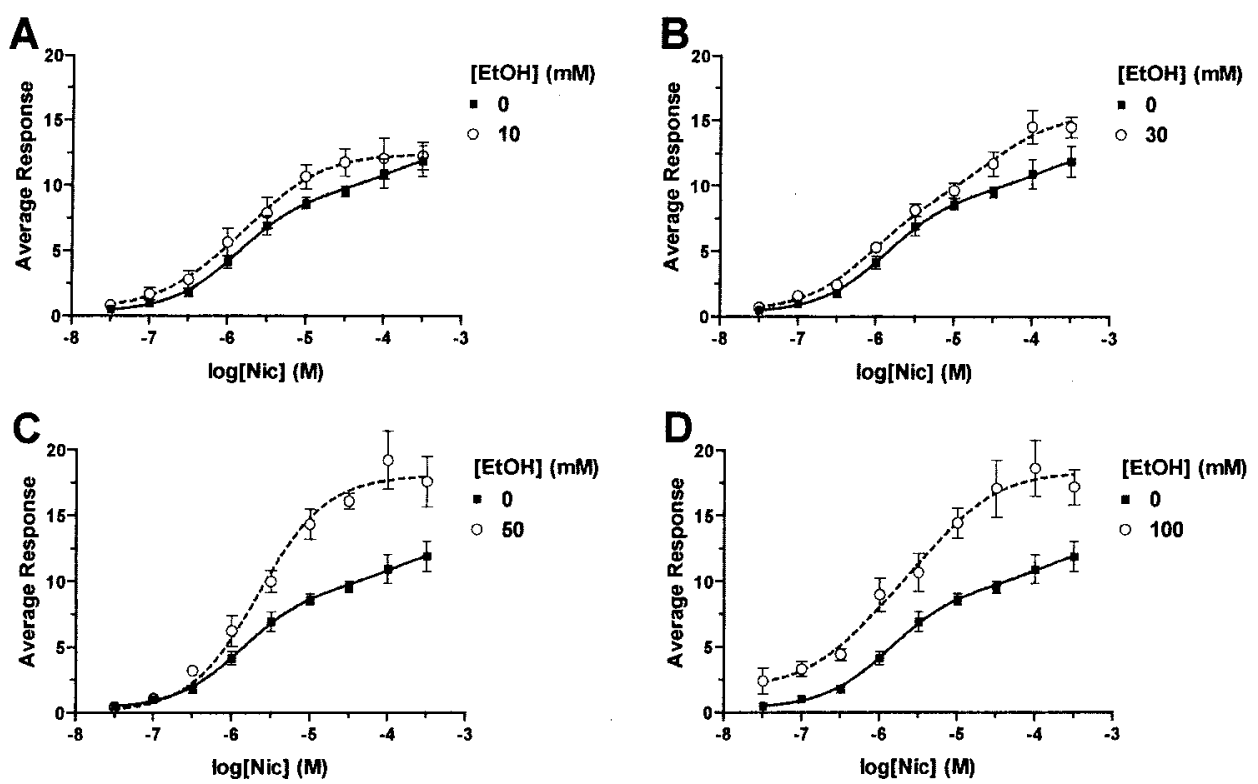

Fig. 3. Effects of ethanol on nicotinestimulated ${ }^{86} \mathrm{Rb}^{+}$efflux from $\mathrm{C} 3 \mathrm{H} / \mathrm{lbg}$ synaptosomes. A, Nicotine $(0.03-300 \mu \mathrm{M})$ concentration-response curves seen under control conditions (no coapplication of ethanol; $0 \mathrm{mM}$; ) versus conditions in which 10 $\mathrm{mM}$ of ethanol was coapplied with nicotine (O). B, Control versus coapplication of $30 \mathrm{mM}$ of ethanol. C, Control versus coapplication of $50 \mathrm{mM}$ of ethanol. D, Control versus coapplication of $100 \mathrm{mM}$ of ethanol. Control data are the same in each panel. Error bars represent the SEM $( \pm$ SEM); $N=4$. Curve fit parameters are compared in Table 1.

these ethanol-present data to a single Michaelis-Menten equation yielded a statistically significant enhancement of receptor function at all three of the higher ethanol concentrations (Table 1). However, only $100 \mathrm{mM}$ of ethanol significantly altered the curve fit parameters when two Michaelis-Menten equations were used. These data showed a significant decrease in $\mathrm{EC}_{50 \mathrm{~L}}(3 \mu \mathrm{M}$ with $100 \mathrm{mM}$ of ethanol vs. $100 \mu \mathrm{M}$ without ethanol) and a significant increase in $\mathrm{V}_{\mathrm{L}}$ (13 units with $100 \mathrm{mM}$ of ethanol vs. 4 units without ethanol; also in Table 1).

Figure 4 shows the effects of coapplied ethanol on the $\mathrm{nAChR}$ activation curve using synaptosomes prepared

Table 1. Effects of Ethanol on Curve Fit Parameters of $n A C h R$ Activation in Synaptosomes Prepared From C3H/lbg (A529) Mice

\begin{tabular}{|c|c|c|c|c|}
\hline \multirow{3}{*}{$\begin{array}{l}\text { [Ethanol] } \\
0 \mathrm{mM} \\
\text { (Control) }\end{array}$} & \multicolumn{2}{|c|}{ Single-site parameters } & \multicolumn{2}{|c|}{ Two-site parameters } \\
\hline & $\mathrm{V}_{\max }$ & $11.0 \pm 0.39$ & $\mathrm{~V}_{\mathrm{H}}$ & $9.32 \pm 1.19$ \\
\hline & & & $\mathrm{EC}_{5 \mathrm{OH}}$ & $1.20 \pm 0.33 \mu \mathrm{M}$ \\
\hline & $\mathrm{EC}_{50}$ & $1.82 \pm 0.37 \mu \mathrm{M}$ & $\begin{array}{l}V_{L} \\
E_{50 L}\end{array}$ & $\begin{aligned} 3.71 & \pm 1.91 \\
126 & \pm 110 \mu \mathrm{M}\end{aligned}$ \\
\hline \multirow[t]{4}{*}{$10 \mathrm{mM}$} & $\mathrm{V}_{\max }$ & $12.1 \pm 0.49$ & $\mathrm{~V}_{\mathrm{H}}$ & $2.11 \pm 3.15^{\star}$ \\
\hline & & & $\mathrm{EC}_{50 \mathrm{H}}$ & $72.0 \pm 68.9 \mathrm{nM}$ \\
\hline & $\mathrm{EC}_{50}$ & $1.23 \pm 0.32 \mu \mathrm{M}$ & $V_{L}$ & $10.3 \pm 3.01$ \\
\hline & & & $\mathrm{EC}_{50 \mathrm{~L}}$ & $2.09 \pm 1.02 \mu \mathrm{M}$ \\
\hline \multirow[t]{4}{*}{$30 \mathrm{mM}$} & $\mathrm{V}_{\max }$ & $13.6 \pm 0.45^{\star \star}$ & $\mathrm{V}_{\mathrm{H}}$ & $8.67 \pm 1.77$ \\
\hline & & & $\mathrm{EC}_{5 \mathrm{OH}}$ & $661 \pm 244 \mathrm{nM}$ \\
\hline & $\mathrm{EC}_{50}$ & $2.00 \pm 0.40 \mu \mathrm{M}$ & $V_{L}$ & $6.87 \pm 1.54$ \\
\hline & & & $\mathrm{EC}_{50 \mathrm{~L}}$ & $30.2 \pm 17.0 \mu \mathrm{M}$ \\
\hline \multirow[t]{4}{*}{$50 \mathrm{mM}$} & $\mathrm{V}_{\max }$ & $18.0 \pm 0.69^{\star \star \star}$ & $\mathrm{V}_{\mathrm{H}}$ & $6.50 \pm 11.1$ \\
\hline & & & $\mathrm{EC}_{5 \mathrm{OH}}$ & $525 \pm 462 \mathrm{nM}$ \\
\hline & $\mathrm{EC}_{50}$ & $2.19 \pm 0.51 \mu \mathrm{M}$ & $V_{L}$ & $12.1 \pm 10.7$ \\
\hline & & & $\mathrm{EC}_{50 \mathrm{~L}}$ & $5.25 \pm 3.80 \mu \mathrm{M}$ \\
\hline \multirow[t]{4}{*}{$100 \mathrm{nM}$} & $\mathrm{V}_{\max }$ & $17.3 \pm 0.79^{\star \star \star}$ & $\mathrm{V}_{\mathrm{H}}$ & $4.70 \pm 2.87$ \\
\hline & & & $\mathrm{EC}_{50 \mathrm{H}}$ & $49.0 \pm 39.7 \mathrm{nM}$ \\
\hline & $\mathrm{EC}_{50}$ & $1.10 \pm 0.32 \mu \mathrm{M}$ & $V_{L}$ & $13.4 \pm 2.73^{\star}$ \\
\hline & & & $\mathrm{EC}_{50 \mathrm{~L}}$ & $3.24 \pm 1.50 \mu \mathrm{M}$ \\
\hline
\end{tabular}

${ }^{\star} p<0.05 ;{ }^{* \star} p<0.01 ;{ }^{\star \star \star} p<0.001$ when compared with control value. $V_{x}$ values are in units above basal ${ }^{86} \mathrm{Rb}^{+}$release (1 unit equals two times basal release). from $\mathrm{C} 57 \mathrm{BL} / 6 \mathrm{~J}$ mice. In these experiments, ethanol decreased the $\mathrm{EC}_{50}$ value of the nicotine activation curve in a concentration-dependent manner but had no consistent effect on the maximum response. When ethanol was used at 30,50 , and $100 \mathrm{mM}$, the $\mathrm{EC}_{50}$ value was significantly smaller than the control value $(\sim 3 \mu \mathrm{M})$. Although $30 \mathrm{mM}$ of ethanol significantly reduced the maximum response, this effect was not seen at higher ethanol concentrations (see Table 2).

These same experiments were also performed in the A/J, AKR/J, Balb/Ibg, and C58/J strains. Strain differences in the responses continued to be detected. Figure 5 shows the effects of ethanol $(50 \mathrm{mM})$ on the nicotine concentrationresponse curves of these four strains. Data obtained from synaptosomes isolated from the A/J (Fig. 5A) and AKR/J (Fig. 5B) strains indicated a significant enhancement of maximal ion flux by ethanol (Table 3). No significant effect of ethanol could be detected in the Balb/Ibg (Fig. 5C) and C58/Ibg (Fig. 5D) strains (Table 3). In all four of these strains, some agonist-induced blockade of the responses may have occurred at the highest nicotine concentration $(300 \mu \mathrm{M})$. However, in no case were these responses significantly different from responses obtained when nicotine was applied at the two other maximally stimulating concentrations (30 and $100 \mu \mathrm{M})$.

\section{Inbred Strains Show Potential Role of A/T Polymorphism in Ethanol Enhancement}

Previous work has established the Chrna4 A/T genotype of the inbred strains used in this study. The A/J, AKR/J, and $\mathrm{C} 3 \mathrm{H} / \mathrm{Ibg}$ strains carry the A529 polymorphism, whereas the Balb/Ibg, C57BL/6J, and C58/J strains have the T529 polymorphism (Dobelis et al., 2002). Figure 6 shows 
Fig. 4. Effects of ethanol on nicotinestimulated ${ }^{86} \mathrm{Rb}^{+}$efflux from C57BL/6J synaptosomes. Coapplication of ethanol with nicotine shifted the nAChR activation curve farther to the left as ethanol concentrations were increased. Average responses were generally enhanced in the middle of the curve when $10 \mathrm{mM}$ (A) $30 \mathrm{mM}$, (B), $50 \mathrm{mM}(\mathrm{C})$, or 100 (D) $\mathrm{mM}$ of ethanol $(\mathrm{O})$ was present during the nicotine stimulation. Control data are the same in each panel. Bars represent the SEM. $N=$ 4-8 for each point. See Table 2 for curve fit parameters.

\section{C57BL/6J}
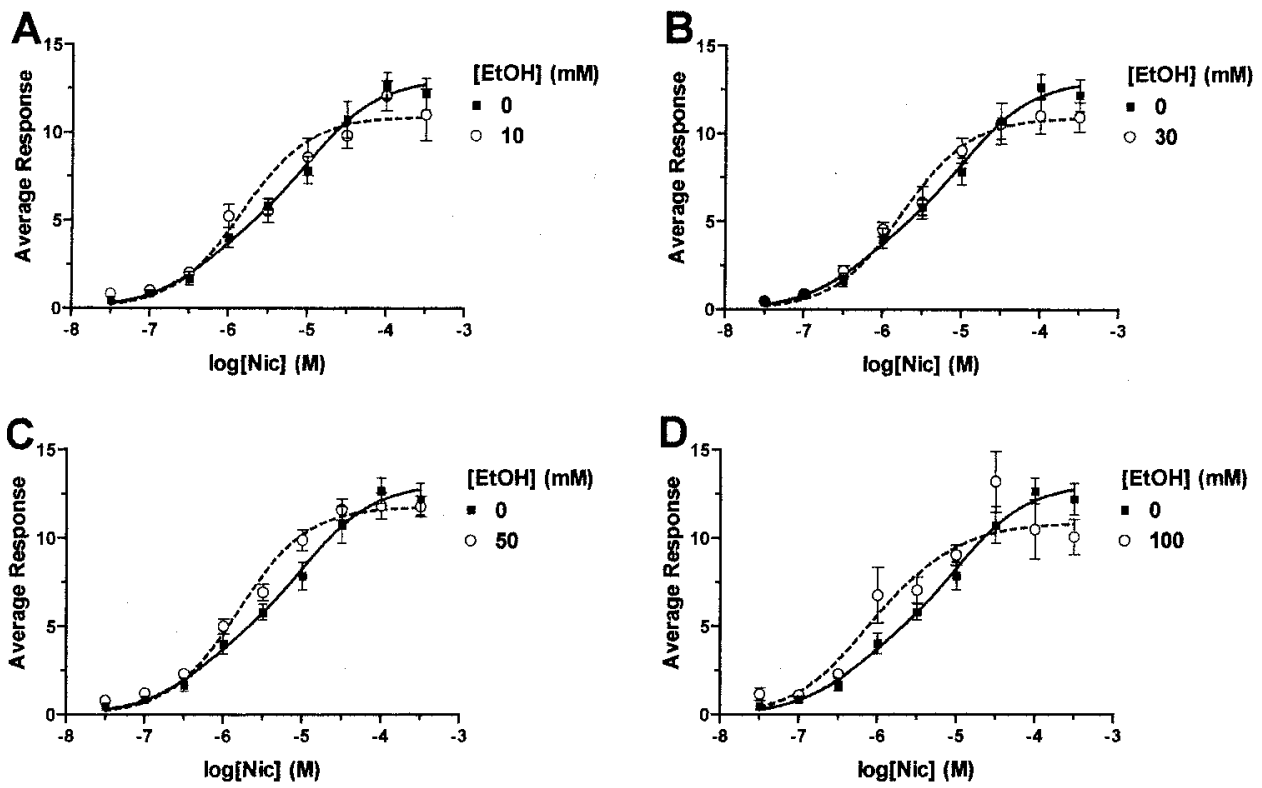

Table 2. Effects of Ethanol on Curve Fit Parameters of nAChR Activation in Synaptosomes Prepared From C57BL/6J (T529) Mice

\begin{tabular}{|c|c|c|c|c|}
\hline \multirow{2}{*}{$\begin{array}{l}\text { [Ethanol] } \\
0 \mathrm{mM} \\
(\text { Control) }\end{array}$} & \multicolumn{2}{|c|}{ Single-site parameters } & \multicolumn{2}{|c|}{ Two-site parameters } \\
\hline & $\mathrm{V}_{\max }$ & $12.4 \pm 0.43$ & $\begin{array}{l}\mathrm{V}_{\mathrm{H}} \\
\mathrm{EC}_{5 \mathrm{OH}}\end{array}$ & $\begin{array}{l}4.74 \pm 3.08 \\
537 \pm 367 \mathrm{nM}\end{array}$ \\
\hline & $\mathrm{EC}_{50}$ & $3.39 \pm 0.78 \mu \mathrm{M}$ & $\begin{array}{l}V_{L} \\
E_{50 L}\end{array}$ & $\begin{array}{l}8.31 \pm 2.85 \\
12.0 \pm 6.65 \mu \mathrm{M}\end{array}$ \\
\hline $10 \mathrm{mM}$ & $\mathrm{V}_{\max }$ & $10.9 \pm 0.50$ & $\begin{array}{l}\mathrm{V}_{\mathrm{H}} \\
\mathrm{EC}_{5 \mathrm{OH}}\end{array}$ & $\begin{array}{l}6.24 \pm 4.09 \\
501 \pm 327 \mathrm{nM}\end{array}$ \\
\hline & $\mathrm{EC}_{50}$ & $1.48 \pm 0.43 \mu \mathrm{M}$ & $\begin{array}{l}\mathrm{V}_{\mathrm{L}} \\
\mathrm{EC}_{50 \mathrm{~L}}\end{array}$ & $\begin{array}{l}5.49 \pm 3.85 \\
11.0 \pm 8.73 \mu \mathrm{M}\end{array}$ \\
\hline $30 \mathrm{mM}$ & $\mathrm{V}_{\max }$ & $10.9 \pm 0.41^{*}$ & $\begin{array}{l}\mathrm{V}_{\mathrm{H}} \\
\mathrm{EC}_{5 \mathrm{OH}}\end{array}$ & $\begin{array}{l}4.20 \pm 4.93 \\
417 \pm 352 \mathrm{nM}\end{array}$ \\
\hline & $\mathrm{EC}_{50}$ & $1.78 \pm 0.36 \mu \mathrm{M}^{\star}$ & $\begin{array}{l}\mathrm{V}_{\mathrm{L}} \\
\mathrm{EC}_{50 \mathrm{~L}}\end{array}$ & $\begin{array}{l}7.10 \pm 4.77 \\
4.79 \pm 3.05 \mu \mathrm{M}\end{array}$ \\
\hline $50 \mathrm{mM}$ & $\mathrm{V}_{\max }$ & $11.8 \pm 0.28$ & $\begin{array}{l}\mathrm{V}_{\mathrm{H}} \\
\mathrm{EC}_{5 \mathrm{OH}}\end{array}$ & $\begin{array}{l}2.94 \pm 2.48 \\
209 \pm 153 \mathrm{nM}\end{array}$ \\
\hline & $\mathrm{EC}_{50}$ & $1.55 \pm 0.19 \mu \mathrm{M}^{\star \star}$ & $\begin{array}{l}\mathrm{V}_{\mathrm{L}} \\
\mathrm{EC}_{50 \mathrm{~L}}\end{array}$ & $\begin{array}{l}9.12 \pm 2.39 \\
3.16 \pm 1.21 \mu \mathrm{M}\end{array}$ \\
\hline $100 \mathrm{mM}$ & $\mathrm{V}_{\max }$ & $10.5 \pm 0.56$ & $\begin{array}{l}\mathrm{V}_{\mathrm{H}} \\
\mathrm{EC}_{5 \mathrm{OH}}\end{array}$ & $\begin{array}{l}8.28 \pm 10.9 \\
575 \pm 455 \mathrm{nM}\end{array}$ \\
\hline & $\mathrm{EC}_{50}$ & $851 \pm 271 \mathrm{nM}^{\star *}$ & $\begin{array}{l}V_{L} \\
E_{50 L}\end{array}$ & $\begin{array}{l}2.54 \pm 10.6 \\
5.62 \pm 5.61 \mu \mathrm{M}\end{array}$ \\
\hline
\end{tabular}

${ }^{*} p<0.05 ;{ }^{* *} p<0.01$ when compared with control value. $V_{x}$ values are in units above basal ${ }^{86} \mathrm{Rb}^{+}$release (1 unit equals two times basal release).

the results of averaging the $\mathrm{nAChR}$ activation curves, in the presence and absence of coapplied ethanol, across strains with the A polymorphism (Fig. 6A) and across strains with the $\mathrm{T}$ polymorphism (Fig. $6 \mathrm{~B}$ ). The A strains exhibited a significant increase in $\mathrm{V}_{\mathrm{L}}$ when ethanol $(50 \mathrm{mM})$ was coapplied with nicotine. Ethanol did not alter nicotinestimulated ion flux in strains that carried the $\mathrm{T}$ variant of the $\alpha 4$ subunit gene.

\section{F2 Analysis of A/T Effects}

F2 hybrids were originally developed to test the reported correlation of the $\mathrm{A} / \mathrm{T}$ polymorphism with behavioral re- sponses to nicotine and ethanol (Tritto et al., 2001, 2002). The F2 intercross animals were derived from a cross between the $\mathrm{A} / \mathrm{J}$ strain and mice containing a null-mutation of the gene encoding the $\beta 2 \mathrm{nAChR}$ subunit. The $\beta 2$ gene deletion had been bred for eight generations onto the C57BL/6J background. The final cross resulted in all nine possible Chrna4/Chrnb2 genotypes as predicted for unlinked genes (Chrna4 is on mouse chromosome 2 and Chrnb2 is on mouse chromosome 3 ), each with two alleles (data not shown).

Dobelis et al. (2002) reported that strains carrying the A variant of the $\alpha 4$ subunit had significantly higher nicotinicagonist stimulated ${ }^{86} \mathrm{Rb}^{+}$efflux than strains carrying the $\mathrm{T}$ variant. Results with the $\mathrm{F} 2$ animals confirmed this observation. As demonstrated in Fig. 7A, the incorporation of a single copy of the A polymorphism was enough to significantly increase the maximal nicotine-stimulated ion flux (A/A $+/+$ and $\mathrm{A} / \mathrm{T}+/+\sim 10.1$ units) when compared with the maximal responses of $\mathrm{T} / \mathrm{T}+/+$ animals (7.69 units; Table 4). This result was also obtained with synaptosomes prepared from animals that were heterozygous for the $\beta 2$ null mutation (Fig. 7B). A/A $+/-$ animals had an average maximal efflux of $\sim 5.5$ units, and $\mathrm{A} / \mathrm{T}+/-$ animals had an average of 5.4 units (Table 4). Both of these values were significantly greater than that seen in $\mathrm{T} / \mathrm{T}+/-$ animals $(4.2$ units; Table 4). Animals that were $\beta 2-/-$ showed little, if any, response to nicotine or nicotine plus ethanol (data not shown). The loss of function seen with the loss of the $\beta 2$ expression is consistent with previous findings (Marks et al., 1999).

The results shown in Fig. 8 suggest that the Chrna4 A/T polymorphism confers ethanol sensitivity to the nAChR. Coapplication of ethanol $(50 \mathrm{mM})$ with nicotine signifi- 

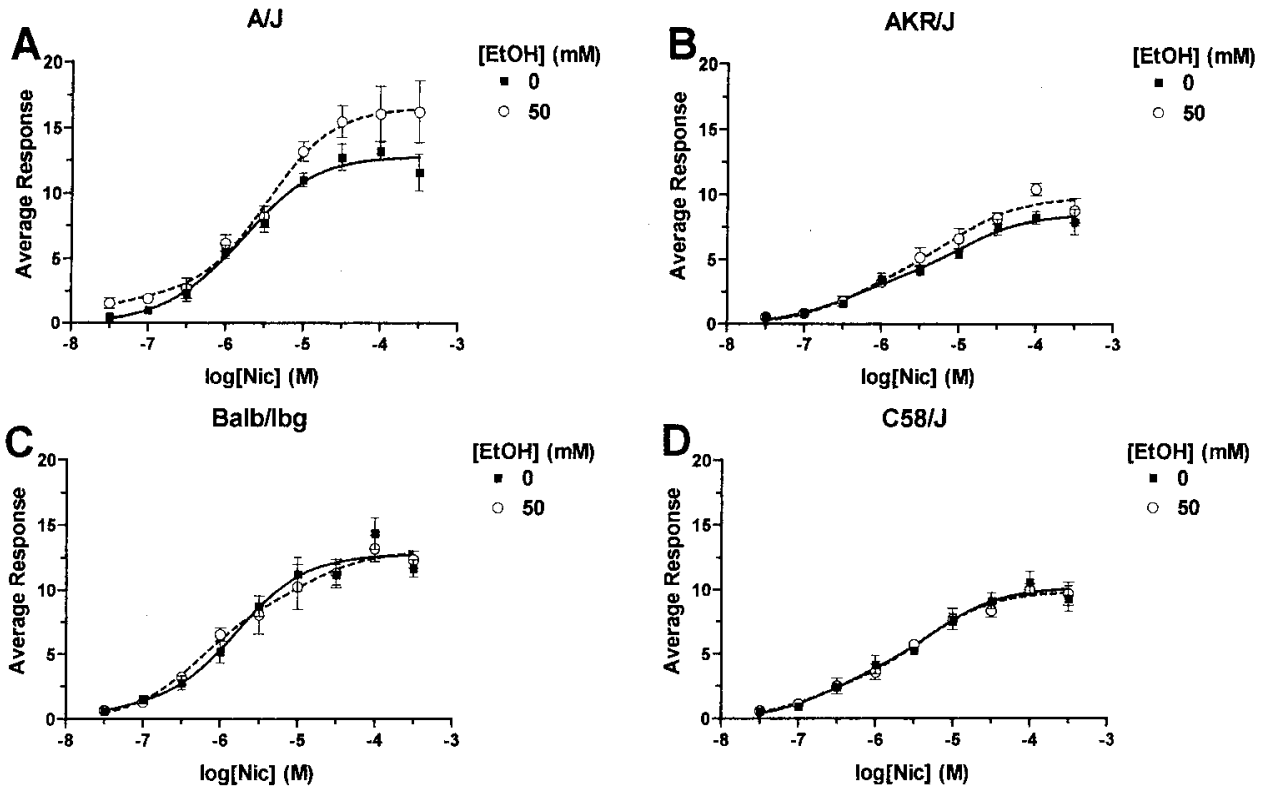

Fig. 5. Comparison of the effects of ethanol $(50 \mathrm{mM})$ on the nicotine concentrationresponse curves in four inbred strains of mice. Synaptosomes prepared from $A / J$ mice $(A)$ and $A K R / J$ mice $(B)$ showed significant enhancement of maximal ion flux by coapplication of ethanol $(\bigcirc)$ compared with nicotineonly controls ( $\square$ ). No effect of ethanol could be detected in tissue samples taken from Balb/lbg mice (C) or C58/lbg mice (D). The curve fit parameters are compared in Table 3 . Bars represent the SEM. $N=4$ for each point.

Table 3. Effects of Ethanol (50 mM) on Curve Fit Parameters of nAChR Activation in Synaptosome Prepared From A/J, AKR/J, Balb/lbg. and C58/J Inbred Mouse Strains

\begin{tabular}{|c|c|c|c|c|c|c|c|}
\hline \multirow[b]{2}{*}{ Strain } & \multirow[b]{2}{*}{ Genotype } & \multicolumn{3}{|c|}{ Single-site parameters } & \multicolumn{3}{|c|}{ Two-site parameters } \\
\hline & & & Control & $\mathrm{EtOH}$ & & Control & $\mathrm{EtOH}$ \\
\hline \multirow[t]{4}{*}{$\mathrm{A} / \mathrm{J}$} & A529 & $\mathrm{V}_{\max }$ & $12.7 \pm 0.42$ & $16.3 \pm 0.76^{*}$ & $V_{H}$ & $2.79 \pm 14.8$ & $2.05 \pm 1.98$ \\
\hline & & & & & $\mathrm{EC}_{5 \mathrm{OH}}$ & $355 \pm 351 \mathrm{nM}$ & $19.5 \pm 19.2 \mathrm{nM}$ \\
\hline & & $\mathrm{EC}_{50}$ & $1.48 \pm 0.30 \mu \mathrm{M}$ & $2.19 \pm 0.63 \mu \mathrm{M}$ & $V_{L}$ & $10.0 \pm 14.6$ & $14.6 \pm 1.92$ \\
\hline & & & & & $\mathrm{EC}_{50 \mathrm{~L}}$ & $2.29 \pm 1.80 \mu \mathrm{M}$ & $3.39 \pm 1.25 \mu \mathrm{M}$ \\
\hline \multirow[t]{4}{*}{$\mathrm{AKR} / \mathrm{J}$} & A529 & $\mathrm{V}_{\max }$ & $7.81 \pm 0.32$ & $9.17 \pm 0.39^{\star}$ & $V_{H}$ & $3.64 \pm 1.38$ & $4.09 \pm 2.52$ \\
\hline & & & & & $\mathrm{EC}_{5 \mathrm{OH}}$ & $331 \pm 176 \mathrm{nM}$ & $457 \pm 295 \mathrm{nM}$ \\
\hline & & $\mathrm{EC}_{50}$ & $1.91 \pm 0.44 \mu \mathrm{M}$ & $2.19 \pm 0.50 \mu \mathrm{M}$ & $V_{L}$ & $4.93 \pm 1.25$ & $5.73 \pm 2.34$ \\
\hline & & & & & $\mathrm{EC}_{5 \mathrm{OL}}$ & $11.5 \pm 6.11 \mu \mathrm{M}$ & $9.55 \pm 5.84 \mu \mathrm{M}$ \\
\hline \multirow[t]{4}{*}{ Balb/lbg } & T529 & $\mathrm{V}_{\max }$ & $12.6 \pm 0.48$ & $12.1 \pm 0.52$ & $V_{H}$ & $1.08 \pm 2.44$ & $8.86 \pm 3.57$ \\
\hline & & & & & $\mathrm{EC}_{5 \mathrm{OH}}$ & $39.8 \pm 39.7 \mathrm{nM}$ & $525 \pm 279 \mathrm{nM}$ \\
\hline & & $\mathrm{EC}_{50}$ & $1.32 \pm 0.30 \mu \mathrm{M}$ & $1.05 \pm 0.27 \mu \mathrm{M}$ & $V_{L}$ & $11.7 \pm 2.34$ & $4.18 \pm 3.26$ \\
\hline & & & & & $\mathrm{EC}_{50 \mathrm{~L}}$ & $1.74 \pm 0.69 \mu \mathrm{M}$ & $14.1 \pm 12.2 \mu \mathrm{M}$ \\
\hline \multirow[t]{4}{*}{ C58/J } & T529 & $V_{\max }$ & $9.63 \pm 0.37$ & $9.41 \pm 0.34$ & $V_{H}$ & $3.86 \pm 2.30$ & $3.18 \pm 1.98$ \\
\hline & & & & & $\mathrm{EC}_{5 \mathrm{OH}}$ & $269 \pm 180 \mathrm{nM}$ & $191 \pm 133 \mathrm{nM}$ \\
\hline & & $\mathrm{EC}_{50}$ & $1.70 \pm 0.39 \mu \mathrm{M}$ & $1.62 \pm 0.37 \mu \mathrm{M}$ & $V_{L}$ & $6.32 \pm 2.16$ & $6.68 \pm 1.87$ \\
\hline & & & & & $\mathrm{EC}_{50 \mathrm{~L}}$ & $6.46 \pm 3.57 \mu \mathrm{M}$ & $5.13 \pm 2.50 \mu \mathrm{M}$ \\
\hline
\end{tabular}

${ }^{*} p<0.05$ when compared with control values. $V_{x}$ values are in units above basal ${ }^{86} \mathrm{Rb}^{+}$release (1 unit equals two times basal release).

cantly increased the maximal efflux in $\mathrm{A} / \mathrm{A}+/+$ animals (12.2 units with ethanol; 10.1 units without ethanol; Fig. $8 \mathrm{~A}$, Table 4). Similar results were seen in the A/T $+/+$ animals (Fig. 8B, Table 4). However, ethanol had no effect on the nicotine concentration-response curves of $\mathrm{T} / \mathrm{T}+/+$ animals (Fig. 8C; Table 4). Use of two Michaelis-Menten equations resulted in better fits to the data in all cases. However, no significant effect of ethanol on $\mathrm{EC}_{50 \mathrm{H}}, \mathrm{V}_{\mathrm{H}}$, $\mathrm{EC}_{50 \mathrm{~L}}$, or $\mathrm{V}_{\mathrm{L}}$ could be detected in these animals (Table 4).

As was observed with the $\beta 2+/+F 2$ animals, ethanol also seemed to change the characteristics of the nAChR activation curve when at least one copy of the A polymorphism gene was present. However, the effect was qualitative only in the $\beta 2$ heterozygotes. Statistically significant effects of $\mathrm{A} / \mathrm{T}$ genotype were not detected in the parameters of the curve fits (Table 4).

\section{DISCUSSION}

The experiments reported here demonstrate that the function of nAChRs native to the adult mouse brain is enhanced by ethanol. The nAChRs expressed in the mouse thalamus contain primarily $\alpha 4$ and $\beta 2$ subunits (Marks et al., 1998, 1999; Zoli et al., 1998). Our results are consistent with what has been reported previously on the effects of alcohol on $\alpha 4 \beta 2$-like nAChRs in cells cultured from the prenatal rat cerebral cortex (Aistrup et al., 1999; Marszalec et al., 1999) and in Xenopus oocytes expressing only $\alpha 4$ and $\beta 2$ subunits (Cardoso et al., 1999). However, our data also demonstrate that a single nucleotide polymorphism may be responsible for conferring ethanol sensitivity to the $\alpha 4 \beta 2$ $\mathrm{nAChR}$ in mice.

Strain differences in responses to nicotine and/or ethanol are well documented. Such differences have been shown 

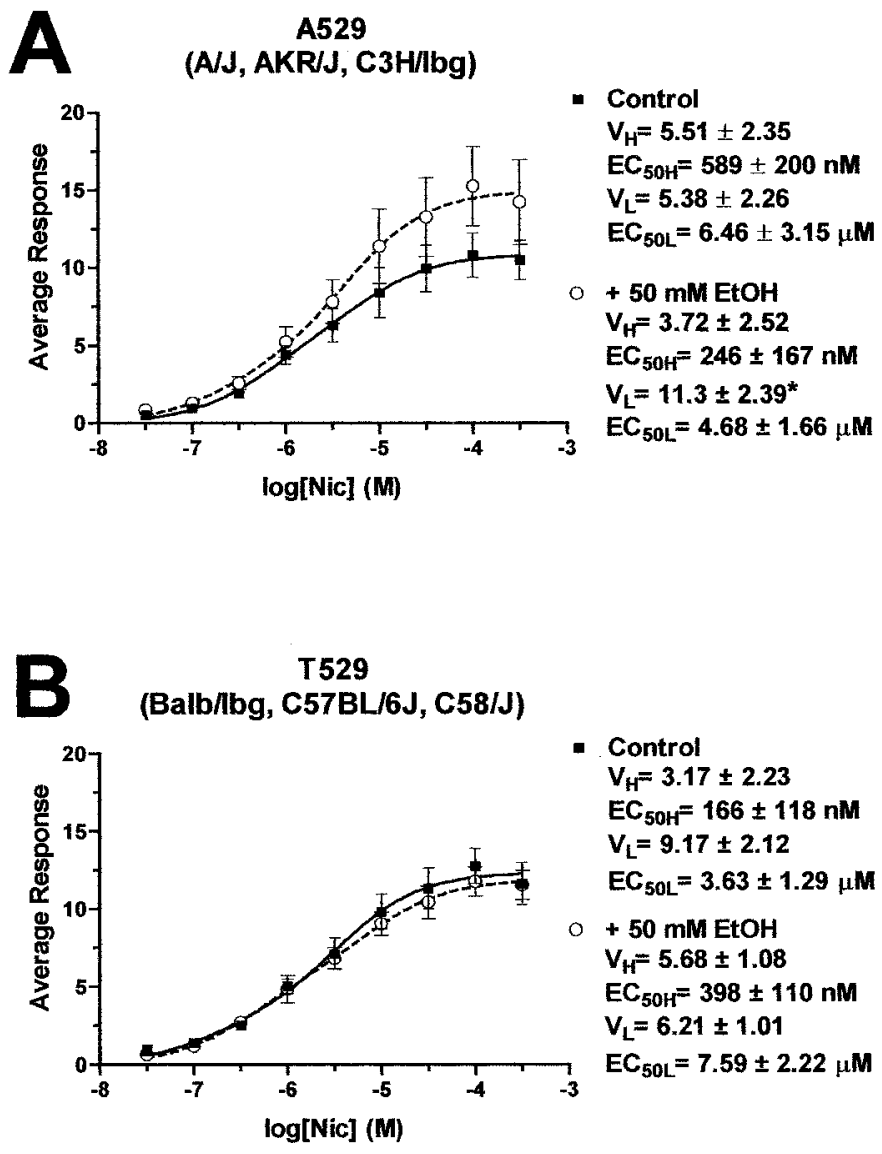

Fig. 6. Average responses to nicotine alone $(\square)$ and nicotine + ethanol (50 $\mathrm{mM}$; $\bigcirc$ ) in mice carrying the A variant (A529) or the T variant (T529) of the $\alpha 4$ polymorphism. A, Nicotinic responses from A529-carrying strains mice exhibit sensitivity to ethanol, whereas (B) strains carrying T529 do not. ${ }^{*} p<0.05$ compared with nicotine-only parameters. Bars represent the SEM. $N=12$ for each point.

repeatedly in behavioral (de Fiebre et al., 1987, 1991; Gill et al., 1998; Marks et al., 1998; Stitzel et al., 2000; Tritto et al., 2001, 2002), neurochemical (Dobelis et al. 2002; Stitzel et al., 2001), and electrophysiological experiments (Slawecki et al., 2000). It is therefore not surprising that we detected strain differences in the sensitivity of nAChR function to ethanol. The unique aspect of the ethanol sensitivity differences reported here was their correlation with the $\mathrm{A} / \mathrm{T}$ polymorphism in the $\alpha 4$ subunit gene. In general, synaptosomes made from mice expressing the Chrna4 A polymorphism showed enhancement of nAChR function by ethanol, whereas nAChRs with the Chrna4 T polymorphism were not affected by acute ethanol exposure.

It is possible that the strain differences in nAChR function and ethanol sensitivity could be due to genes that are linked to the gene encoding the $\alpha 4 \mathrm{nAChR}$ subunit. The reported Chrna4 A/T differences in basal ${ }^{86} \mathrm{Rb}^{+}$flux reported previously are derived from the average nicotine (10 $\mu \mathrm{M})$ responses of synaptosomes prepared from 14 inbred mouse strains (Dobelis et al., 2002). However, close inspection of our data indicates that some Chrna4 A-containing strains (e.g., AKR/J) have lower maximal efflux than some
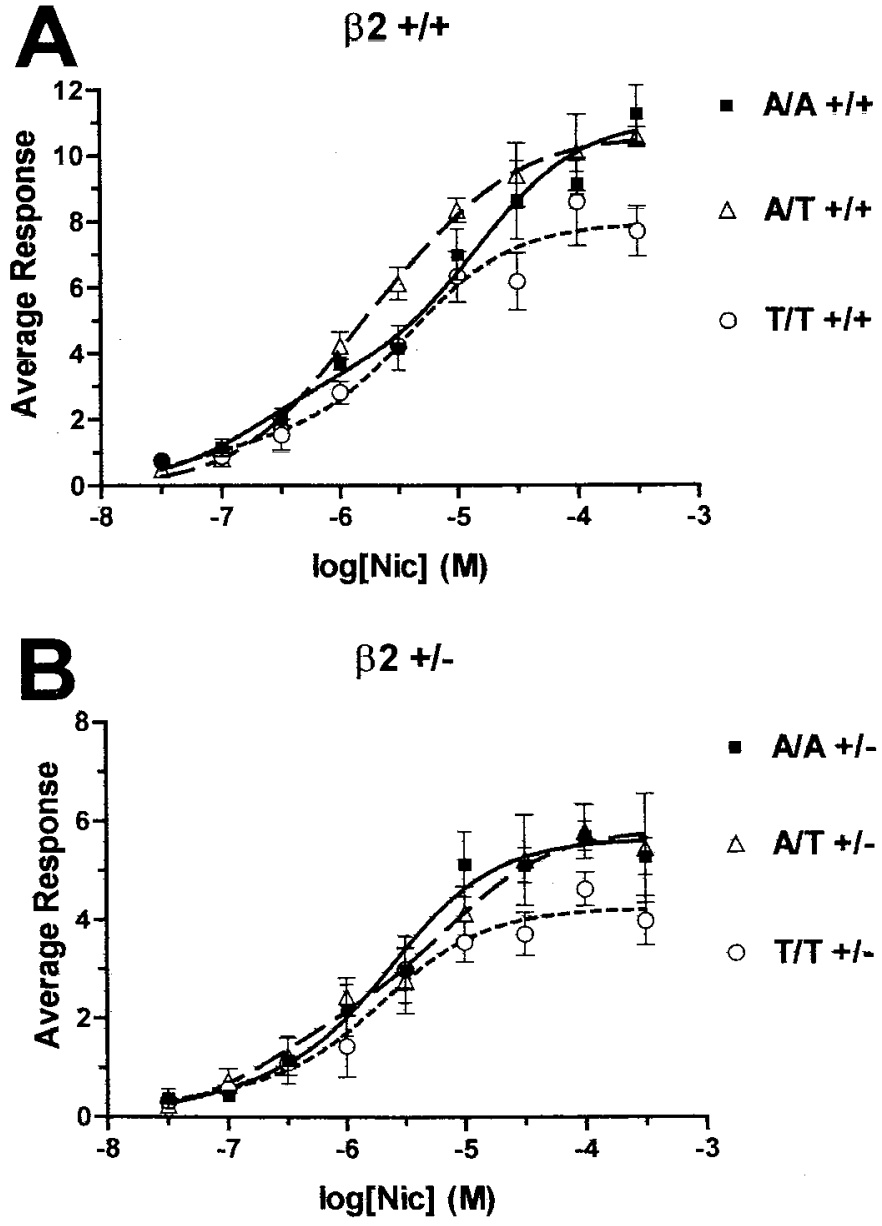

Fig. 7. Effects of the $A / T$ polymorphism on nicotine-stimulated ${ }^{86} \mathrm{Rb}^{+}$efflux from synaptosomes prepared from (C57BL/6J $\times \beta 2-/-) \times A / J$ F2 hybrids. Animals carrying at least one copy of the A529 gene had significantly higher maximal ${ }^{86} \mathrm{Rb}^{+}$flux than homozygous T529 animals. This occurred in both (A) $\beta 2$ $+/+$ animals and (B) $\beta 2+/-$ animals. There was no significant difference in maximal efflux when $A / A$ and $A / T$ animals were compared. Bars represent the SEM. $N=4$ for each point. Curve fit parameters can be found in Table 4 .

T-containing strains (e.g., Balb/Ibg) even when ethanol is coapplied. This finding suggests that genes linked to the $\alpha 4$ subunit gene or genes in addition to the $\alpha 4$ subunit gene may affect the nicotine-stimulated ${ }^{86} \mathrm{Rb}^{+}$flux response. Indeed, genetic background may compensate for the deletion of genes thought to be important for initial sensitivity to ethanol, ethanol tolerance (Bowers et al., 1999), and ethanol consumption (Phillips et al., 1999). These problems led us to test the F2 intercross mice in this study. Making the F2 animals allowed for an analysis of the Chrna4 polymorphism in a mixture of only 2 genetic backgrounds instead of the 14 genetic backgrounds evaluated by Dobelis et al. (2002). The F2 data clearly show that being heterozygous for the A variant of the $\alpha 4$ subunit is sufficient to increase ion flux through the $\alpha 4 \beta 2 \mathrm{nAChR}$ and imparts ethanol sensitivity to this receptor. Synaptosomes made from F2 animals with a T/T genotype have significantly lower nicotine-stimulated ${ }^{86} \mathrm{Rb}^{+}$flux when compared with $\mathrm{A} / \mathrm{A}$ and $\mathrm{A} / \mathrm{T}$ animals, and the $\mathrm{T} / \mathrm{T}$ responses are insensitive 


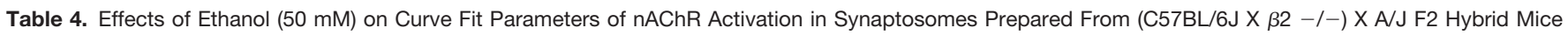

\begin{tabular}{|c|c|c|c|c|c|c|}
\hline \multirow[b]{2}{*}{ Genotype } & \multicolumn{3}{|c|}{ Single-site parameters } & \multicolumn{3}{|c|}{ Two-site parameters } \\
\hline & & Control & $\mathrm{EtOH}$ & & Control & $\mathrm{EtOH}$ \\
\hline \multirow[t]{2}{*}{$\mathrm{A} / \mathrm{A}+/+$} & $V_{\max }$ & $10.1 \pm 0.49 \ddagger$ & $12.2 \pm 0.58^{\star} \ddagger$ & $\begin{array}{l}\mathrm{V}_{\mathrm{H}} \\
\mathrm{EC}_{50 \mathrm{H}}\end{array}$ & $\begin{aligned} 3.47 & \pm 1.13 \\
200 & \pm 116 \mathrm{nM}\end{aligned}$ & $\begin{array}{l}2.13 \pm 1.58 \\
26.3 \pm 25.0 \mathrm{nM}\end{array}$ \\
\hline & $\mathrm{EC}_{50}$ & $3.16 \pm 1.30 \mu \mathrm{M}$ & $2.57 \pm 1.05 \mu \mathrm{M}$ & $\begin{array}{l}\mathrm{V}_{\mathrm{L}} \\
\mathrm{EC}_{50 \mathrm{~L}}\end{array}$ & $\begin{array}{l}7.60 \pm 1.06 \\
15.1 \pm 6.43 \mu \mathrm{M}\end{array}$ & $\begin{array}{l}10.5 \pm 1.60 \dagger \\
5.37 \pm 2.55 \mu \mathrm{M}\end{array}$ \\
\hline \multirow[t]{2}{*}{$\mathrm{A} / \mathrm{T}+/+$} & $V_{\max }$ & $10.1 \pm 0.32 \ddagger$ & $11.7 \pm 0.49^{\star} \ddagger$ & $\begin{array}{l}\mathrm{V}_{\mathrm{H}} \\
\mathrm{EC}_{5 \mathrm{OH}}\end{array}$ & $\begin{aligned} 6.32 & \pm 4.37 \\
724 & \pm 436 \mathrm{nM}\end{aligned}$ & $\begin{array}{l}1.42 \pm 1.68 \\
56.2 \pm 54.0 \mathrm{nM}\end{array}$ \\
\hline & $\mathrm{EC}_{50}$ & $1.66 \pm 0.29 \mu \mathrm{M}$ & $2.29 \pm 0.53 \mu \mathrm{M}$ & $\begin{array}{l}V_{L} \\
\mathrm{EC}_{50 \mathrm{~L}}\end{array}$ & $\begin{array}{l}4.25 \pm 4.16 \\
8.71 \pm 7.01 \mu \mathrm{M}\end{array}$ & $\begin{array}{l}10.5 \pm 1.59 \dagger \\
3.47 \pm 0.96 \mu \mathrm{M}\end{array}$ \\
\hline \multirow[t]{2}{*}{$\mathrm{T} / \mathrm{T}+/+$} & $V_{\max }$ & $7.69 \pm 0.41$ & $7.73 \pm 0.28$ & $\begin{array}{l}\mathrm{V}_{\mathrm{H}} \\
\mathrm{EC}_{5 \mathrm{OH}}\end{array}$ & $\begin{array}{l}1.42 \pm 1.39 \\
60.3 \pm 56.0 \mathrm{nM}\end{array}$ & $\begin{array}{l}3.19 \pm 1.37 \\
245 \pm 143 \mathrm{nM}\end{array}$ \\
\hline & $\mathrm{EC}_{50}$ & $2.04 \pm 0.65 \mu \mathrm{M}$ & $1.74 \pm 0.35 \mu \mathrm{M}$ & $\begin{array}{l}\mathrm{V}_{\mathrm{L}} \\
\mathrm{EC}_{50 \mathrm{~L}}\end{array}$ & $\begin{array}{l}6.54 \pm 1.32 \\
4.07 \pm 1.94 \mu \mathrm{M}\end{array}$ & $\begin{array}{l}5.07 \pm 1.28 \\
7.76 \pm 3.78 \mu \mathrm{M}\end{array}$ \\
\hline \multirow[t]{2}{*}{$\mathrm{A} / \mathrm{A}+/-$} & $\mathrm{V}_{\max }$ & $5.53 \pm 0.26 \ddagger$ & $5.92 \pm 0.34 \ddagger$ & $\begin{array}{l}\mathrm{V}_{\mathrm{H}} \\
\mathrm{EC}_{5 \mathrm{OH}}\end{array}$ & $\begin{array}{l}0.65 \pm 1.28 \\
64.5 \pm 63.7 \mathrm{nM}\end{array}$ & $\begin{aligned} 2.27 & \pm 0.98 \\
105 & \pm 73.1 \mathrm{nM}\end{aligned}$ \\
\hline & $\mathrm{EC}_{50}$ & $1.74 \pm 0.50 \mu \mathrm{M}$ & $1.55 \pm 0.59 \mu \mathrm{M}$ & $\begin{array}{l}\mathrm{V}_{\mathrm{L}} \\
\mathrm{EC}_{50 \mathrm{~L}}\end{array}$ & $\begin{array}{l}4.97 \pm 1.21 \\
2.51 \pm 1.19 \mu \mathrm{M}\end{array}$ & $\begin{array}{l}4.19 \pm 0.93 \\
8.51 \pm 4.62 \mu \mathrm{M}\end{array}$ \\
\hline \multirow[t]{2}{*}{$\mathrm{A} / \mathrm{T}+/-$} & $V_{\max }$ & $5.44 \pm 0.35 \dagger$ & $5.69 \pm 0.42 \ddagger$ & $\begin{array}{l}\mathrm{V}_{\mathrm{H}} \\
\mathrm{EC}_{5 \mathrm{OH}}\end{array}$ & $\begin{array}{l}2.14 \pm 1.78 \\
234 \pm 195 \mathrm{nM}\end{array}$ & $\begin{array}{l}3.83 \pm 1.59 \\
275 \pm 180 \mathrm{nM}\end{array}$ \\
\hline & $\mathrm{EC}_{50}$ & $1.86 \pm 0.77 \mu \mathrm{M}$ & $813 \pm 417 \mathrm{nM}$ & $\begin{array}{l}V_{L} \\
E_{50 L}\end{array}$ & $\begin{array}{l}3.67 \pm 1.66 \\
7.94 \pm 5.60 \mu \mathrm{M}\end{array}$ & $\begin{array}{l}2.58 \pm 1.47 \\
18.2 \pm 16.1 \mu \mathrm{M}\end{array}$ \\
\hline \multirow[t]{2}{*}{$\mathrm{T} / \mathrm{T}+/-$} & $\mathrm{V}_{\max }$ & $4.15 \pm 0.21$ & $3.68 \pm 0.28$ & $\begin{array}{l}\mathrm{V}_{\mathrm{H}} \\
\mathrm{EC}_{5 \mathrm{OH}}\end{array}$ & $\begin{array}{l}0.51 \pm 0.78 \\
25.7 \pm 25.5 \mathrm{nM}\end{array}$ & $\begin{array}{l}0.78 \pm 0.60 \\
12.9 \pm 12.7 \mathrm{nM}\end{array}$ \\
\hline & $\mathrm{EC}_{50}$ & $1.38 \pm 0.44 \mu \mathrm{M}$ & $1.66 \pm 0.85 \mu \mathrm{M}$ & $\begin{array}{l}V_{L} \\
\mathrm{EC}_{50 \mathrm{~L}}\end{array}$ & $\begin{array}{l}3.71 \pm 0.75 \\
2.09 \pm 0.97 \mu \mathrm{M}\end{array}$ & $\begin{array}{l}3.04 \pm 0.60 \\
3.89 \pm 2.12 \mu \mathrm{M}\end{array}$ \\
\hline
\end{tabular}

${ }^{*} p<0.05$ when compared with control value. $\dagger p<0.05 ; \ddagger p<0.01$ when compared with appropriate $\mathrm{T} / \mathrm{T} \beta 2+/ \mathrm{x}$ value. $\mathrm{V}_{\mathrm{y}}$ values are in units above basal ${ }^{86} \mathrm{Rb}{ }^{+}$ release (1 unit equals two times basal release).

to behaviorally relevant ethanol concentrations. Consistent with the A variant of the $\alpha 4$ subunit being sensitive to the potentiating effects of alcohol in mice, the cDNA sequence for the rat $\alpha 4$ subunit codes for an alanine in the second cytoplasmic loop at a position that corresponds to the A/T polymorphism in mouse Chrna4 (Goldman et al., 1987). It is well documented that the function of the rat $\alpha 4 \beta 2$ nAChR is potentiated by ethanol (Aistrup et al., 1999; Cardoso et al., 1999; Marszalec et al., 1999).

The underlying details of how the Chrna4 A polymorphism increases the ion flux and ethanol sensitivity of the $\alpha 4 \beta 2 \mathrm{nAChR}$ are not understood, but several possibilities exist. The region of the $\alpha 4$ subunit in which the polymorphism occurs, the second and largest cytoplasmic loop, is important for receptor desensitization (Gross et al., 1991), subunit-specific receptor trafficking (Williams et al., 1998), and possibly filtering of the ions through the receptor's pore (Miyazawa et al., 1999). Phosphorylation is known to play a role in receptor desensitization and recovery from desensitization (Fenster et al., 1999). Analysis of the amino acid sequence surrounding the Chrna4 $\mathrm{A} / \mathrm{T}$ polymorphism suggests that introducing a threonine at residue 529 may produce a phosphorylation site for casein kinase I. Sequence analysis also predicts that the serine at position 530 [DQ (A/T) SPCK] could be phosphorylated by kinases in the cdc2 family, such as Cdk5 (Dobelis et al., 2002). Therefore, the presence or absence of phosphorylation at residue 529 could change the phosphorylation potential of serine 530. Because phosphorylation can modulate changes in secondary or tertiary protein structure, the Chrna4 A/T polymorphism might alter the ability of the $\alpha 4$ subunit to interact with other subunits or change the activation state of the receptor. Structural changes might also explain the $\mathrm{A} / \mathrm{T}$ differences in ethanol sensitivity of the $\mathrm{nAChR}$ in that the structure of the A variant may uncover an ethanol interaction site that is not present in $\mathrm{T} / \mathrm{T}$ nAChRs.

When ethanol enhances the function of $\alpha 4$ subunit A-variant nAChRs, it seems to have its strongest effects on the low-affinity component of activation. This mimics the action of BSA, which also exerts most of its effects at the low-affinity activation component. Enhancement of nAChR function by BSA seems to be caused by the removal of inhibitory long-chain fatty acids by their binding to BSA (Butt et al., 2002). Long-chain alcohols, which have some similarity to long-chain fatty acids, also have inhibitory effects on nAChR function (Wood et al., 1991; Zuo et al., 2001). BSA decreases the degree to which ethanol enhances nAChR function compared with control values, and short-chain alcohols (e.g., ethanol) interact noncompetitively with the long-chain alcohol binding site on the nAChR (Zuo et al., 2001). Thus, it seems that $\alpha 4$ subunit A-variant nAChRs may have ethanol interaction sites that could allow for the noncompetitive removal of inhibitory fatty acids from the $\mathrm{nAChR}$, whereas $\mathrm{T} / \mathrm{T} \mathrm{nAChRs}$ do not. This could explain why ethanol enhancement is seen best under conditions in which BSA is absent. In contrast, $\mathrm{nAChR}$ function is probably near its ceiling when BSA is present. Therefore, there is decreased probability of detecting an ethanol effect on the inhibitory long-chain alcohol/ fatty acid binding site.

In summary, our results suggest that the Chrna4 $\mathrm{A} / \mathrm{T}$ polymorphism is responsible for altering $\alpha 4 \beta 2 \mathrm{nAChR}$ function and sensitivity of this receptor to ethanol. Although the mechanisms of the polymorphism's effects are 

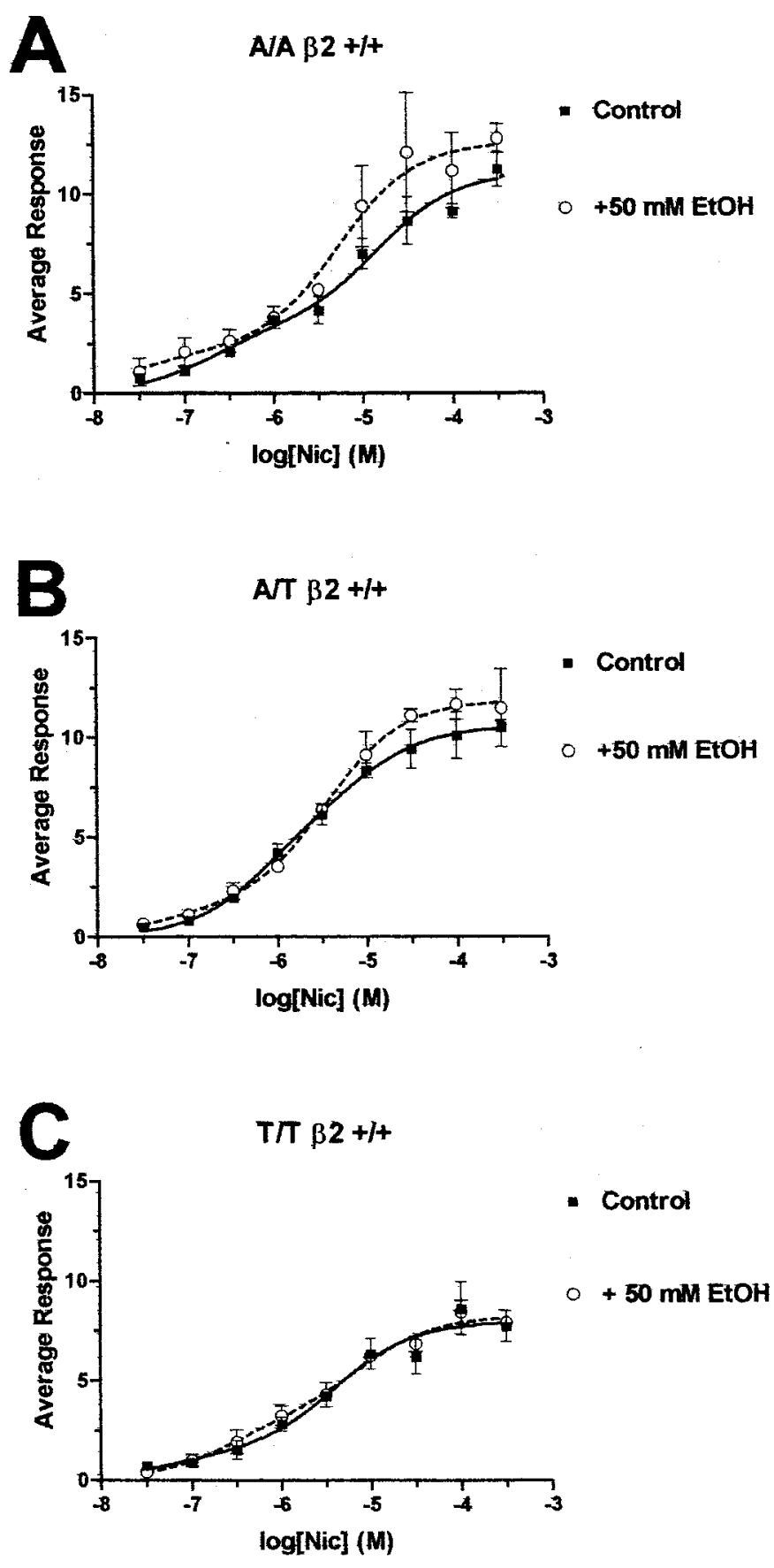

Fig. 8. Effects of ethanol $(50 \mathrm{mM})$ on nicotine-stimulated ${ }^{86} \mathrm{Rb}^{+}$efflux from synaptosomes prepared from $\beta 2+/+F 2$ hybrids. A, Maximal ion flux was significantly enhanced by acute ethanol in animals that were homozygous $A$ for the $\alpha 4$ polymorphism. B. The enhancing effect of ethanol was diminished in AVT animals and was not seen in homozygous $T$ animals $(C)$. Bars represent the SEM. $N=4$ for each point. A comparison of the curve fits is in Table 4 .

unclear, it is reasonable to conclude that the data that we have obtained may be due to the polymorphism. Applying this interpretation to the data from Gill et al. (1998) suggests that alcohol consumption is increased when ethanol has little effect on the function of $\alpha 4 \beta 2$ nAChRs. This could mean that the behavioral effects of ethanol in strains that possess the T529 variant of Chrna4 are due to other genes, which is consistent with the polygenic nature of alcohol's effects. It is also consistent with the findings that a low, initial response to alcohol correlates with a family history of alcoholism in humans and with a region in human chromosome 20 that contains CHRNA4, the gene encoding the human $\alpha 4$ nAChR subunit (Schuckit et al., 2001).

\section{ACKNOWLEDGMENTS}

We thank Natalie Meinerz for assistance with the genotyping of the F2 animals used in this study.

\section{REFERENCES}

Aistrup GL, Marszalec W, Narahashi T (1999) Ethanol modulation of nicotinic acetylcholine receptor currents in cultured cortical neurons. Mol Pharmacol 55:39-49.

Batel P, Pessione F, Maitre C, Rueff B (1995) Relationship between alcohol and tobacco dependencies among alcoholics who smoke. Addiction 90:977-980.

Bessis A, Simon-Chazottes D, Devillers-Thiery A, Guenet JL, Changeux JP (1990) Chromosomal localization of the mouse genes coding for alpha 2, alpha 3, alpha 4 and beta 2 subunits of neuronal nicotinic acetylcholine receptor. FEBS Lett 264:48-52.

Bowers BJ, Owen EH, Collins AC, Abeliovich A, Tonegawa S, Wehner JM (1999) Decreased ethanol sensitivity and tolerance development in gamma- protein kinase $\mathrm{C}$ null mutant mice is dependent on genetic background. Alcohol Clin Exp Res 23:387-397.

Butt CM, Hutton SR, Marks MJ, Collins AC (2002) Bovine serum albumin enhances nicotinic acetylcholine receptor function in mouse thalamic synaptosomes. J Neurochem 83:48-56.

Cardoso RA, Brozowski SJ, Chavez-Noriega LE, Harpold M, Valenzuela CF, Harris RA (1999) Effects of ethanol on recombinant human neuronal nicotinic acetylcholine receptors expressed in Xenopus oocytes. J Pharmacol Exp Ther 289:774-780.

Collins AC (1996) The nicotinic cholinergic receptor as a potential site of ethanol action, in Pharmacological effects of ethanol on the nervous system (Deitrich RA, Erwin VG eds), pp 95-115. CRC Press, Boca Raton, FL.

de Fiebre CM, Collins AC (1988) Decreased sensitivity to nicotineinduced seizures as a consequence of nicotine pretreatment in longsleep and short-sleep mice. Alcohol 5:55-61.

de Fiebre CM, Collins AC (1989) Behavioral desensitization to nicotine is enhanced differentially by ethanol in long-sleep and short-sleep mice. Alcohol 6:45-51.

de Fiebre CM, Collins AC (1992) Classical genetic analyses of responses to nicotine and ethanol in crosses derived from long- and short-sleep mice. J Pharmacol Exp Ther 261:173-180.

De Fiebre CM, Medhurst LJ, Collins AC (1987) Nicotine response and nicotinic receptors in long-sleep and short-sleep mice. Alcohol 4:493501.

de Fiebre CM, Romm E, Collins JT, Draski LJ, Deitrich RA, Collins AC (1991) Responses to cholinergic agonists of rats selectively bred for differential sensitivity to ethanol. Alcohol Clin Exp Res 15:270-276.

Deneris ES, Boulter J, Connolly J, Wada E, Wada K, Goldman D, Swanson LW, Patrick J, Heinemann S (1989) Genes encoding neuronal nicotinic acetylcholine receptors. Clin Chem 35:731-737.

Deneris ES, Connolly J, Boulter J, Wada E, Wada K, Swanson LW, Patrick J, Heinemann S (1988) Primary structure and expression of beta 2: a novel subunit of neuronal nicotinic acetylcholine receptors. Neuron $1: 45-54$.

Dobelis P, Marks MJ, Whiteaker P, Balogh SA, Collins AC, Stitzel JA (2002) A polymorphism in the mouse neuronal alpha4 nicotinic receptor subunit results in an alteration in receptor function. Mol Pharmacol 62:334-342. 
Fenster CP, Beckman ML, Parker JC, Sheffield EB, Whitworth TL, Quick MW, Lester RA (1999) Regulation of alpha4beta2 nicotinic receptor desensitization by calcium and protein kinase C. Mol Pharmacol 55: 432-443.

Flores CM, Rogers SW, Pabreza LA, Wolfe BB, Kellar KJ (1992) A subtype of nicotinic cholinergic receptor in rat brain is composed of alpha 4 and beta 2 subunits and is up-regulated by chronic nicotine treatment. Mol Pharmacol 41:31-37.

Gill K, Desaulniers N, Desjardins P, Lake K (1998) Alcohol preference in $\mathrm{AXB} / \mathrm{BXA}$ recombinant inbred mice: gender differences and genderspecific quantitative trait loci. Mamm Genome 9:929-935.

Goldman D, Deneris E, Luyten W, Kochhar A, Patrick J, Heinemann S (1987) Members of a nicotinic acetylcholine receptor gene family are expressed in different regions of the mammalian central nervous system. Cell 48:965-973.

Goldman D, Simmons D, Swanson LW, Patrick J, Heinemann S (1986) Mapping of brain areas expressing RNA homologous to two different acetylcholine receptor alpha-subunit cDNAs. Proc Natl Acad Sci USA 83:4076-4080.

Gross A, Ballivet M, Rungger D, Bertrand D (1991) Neuronal nicotinic acetylcholine receptors expressed in Xenopus oocytes: role of the alpha subunit in agonist sensitivity and desensitization. Pflugers Arch 419: $545-551$.

Gurantz D, Margiotta JF, Harootunian AT, Dionne VE (1993) Modulation by albumin of neuronal cholinergic sensitivity. Mol Pharmacol 43:807-812.

Hancock AA, Bush EN, Stanisic D, Kynci JJ, Lin CT (1988) Data normalization before statistical analysis: keeping the horse before the cart. Trends Pharmacol Sci 9:29-32.

Hettema JM, Corey LA, Kendler KS (1999) A multivariate genetic analysis of the use of tobacco, alcohol, and caffeine in a population based sample of male and female twins. Drug Alcohol Depend 57:69-78.

Hughes JR (1993) Treatment of smoking cessation in smokers with past alcohol/drug problems. J Subst Abuse Treat 10:181-187.

Le Novère N, Zoli M, Changeux JP (1996) Neuronal nicotinic receptor alpha 6 subunit mRNA is selectively concentrated in catecholaminergic nuclei of the rat brain. Eur J Neurosci 8:2428-2439.

Marks MJ, Pauly JR, Gross SD, Deneris ES, Hermans-Borgmeyer I, Heinemann SF, Collins AC (1992) Nicotine binding and nicotinic receptor subunit RNA after chronic nicotine treatment. J Neurosci 12: 2765-2784.

Marks MJ, Robinson SF, Collins AC (1996) Nicotinic agonists differ in activation and desensitization of $86 \mathrm{Rb}+$ efflux from mouse thalamic synaptosomes. J Pharmacol Exp Ther 277:1383-1396.

Marks MJ, Smith KW, Collins AC (1998) Differential agonist inhibition identifies multiple epibatidine binding sites in mouse brain. J Pharmacol Exp Ther 285:377-386.

Marks MJ, Whiteaker P, Calcaterra J, Stitzel JA, Bullock AE, Grady SR, Picciotto MR, Changeux JP, Collins AC (1999) Two pharmacologically distinct components of nicotinic receptor-mediated rubidium efflux in mouse brain require the beta2 subunit. J Pharmacol Exp Ther 289: 1090-1103.

Marszalec W, Aistrup GL, Narahashi T (1999) Ethanol-nicotine interactions at alpha-bungarotoxin-insensitive nicotinic acetylcholine receptors in rat cortical neurons. Alcohol Clin Exp Res 23:439-445.

Marubio LM, del Mar Arroyo-Jimenez M, Cordero-Erausquin M, Lena C, Le Novere N, de Kerchove d'Exaerde A, Huchet M, Damaj MI, Changeux JP (1999) Reduced antinociception in mice lacking neuronal nicotinic receptor subunits. Nature 398:805-810.

Miyazawa A, Fujiyoshi Y, Stowell M, Unwin N (1999) Nicotinic acetylcholine receptor at $4.6 \mathrm{~A}$ resolution: transverse tunnels in the channel wall. J Mol Biol 288:765-786.

Orr-Urtreger A, Goldner FM, Saeki M, Lorenzo I, Goldberg L, De Biasi M, Dani JA, Patrick JW, Beaudet AL (1997) Mice deficient in the alpha7 neuronal nicotinic acetylcholine receptor lack alphabungarotoxin binding sites and hippocampal fast nicotinic currents. J Neurosci 17:9165-9171.

Owens JC, Balogh SA, McClure-Begley TD, Labarca C, Lester HA, Piccioto MR, Wehner JM, Collins AC (2002) Nicotine and ethanol modulation of acoustic startle and hypothermia is mediated by alpha4/ beta2 neuronal nicotinic receptors (abstract). Soc Neurosci Abstr 783.2.

Phillips TJ, Hen R, Crabbe JC (1999) Complications associated with genetic background effects in research using knockout mice. Psychopharmacology (Berl) 147:5-7.

Picciotto MR, Zoli M, Lena C, Bessis A, Lallemand Y, LeNovere N, Vincent P, Pich EM, Brulet P, Changeux JP (1995) Abnormal avoidance learning in mice lacking functional high-affinity nicotine receptor in the brain. Nature 374:65-67.

Ross SA, Wong JY, Clifford JJ, Kinsella A, Massalas JS, Horne MK, Scheffer IE, Kola I, Waddington JL, Berkovic SF, Drago J (2000) Phenotypic characterization of an alpha 4 neuronal nicotinic acetylcholine receptor subunit knock-out mouse. J Neurosci 20:6431-6441.

Schuckit MA, Edenberg HJ, Kalmijn J, Flury L, Smith TL, Reich T, Bierut L, Goate A, Foroud T (2001) A genome-wide search for genes that relate to a low level of response to alcohol. Alcohol Clin Exp Res 25:323-329.

Slawecki CJ, Betancourt M, Li TK, Ehlers CL (2000) Neurophysiological findings and drinking levels in high-alcohol-drinking (HAD) and lowalcohol-drinking (LAD) rats Alcohol Clin Exp Res 24:1492-1499.

Stitzel JA, Dobelis P, Jimenez M, Collins AC (2001) Long sleep and short sleep mice differ in nicotine-stimulated $86 \mathrm{Rb}+$ efflux and alpha4 nicotinic receptor subunit cDNA sequence. Pharmacogenetics 11:331-339.

Stitzel JA, Lu Y, Jimenez M, Tritto T, Collins AC (2000) Genetic and pharmacological strategies identify a behavioral function of neuronal nicotinic receptors. Behav Brain Res 113:57-64.

Tritto T, Dudek BC (1994) Differential activating effects of ethanol in C57BL/6Abg and DBA/2Abg mice. Alcohol 11:133-139.

Tritto T, Marley RJ, Bastidas D, Stitzel JA, Collins AC (2001) Potential regulation of nicotine and ethanol actions by alpha4-containing nicotinic receptors. Alcohol 24:69-78.

Tritto T, Stitzel JA, Marks MJ, Romm E, Collins AC (2002) Variability in response to nicotine in the LSxSS RI strains: potential role of polymorphisms in alpha4 and alpha6 nicotinic receptor genes. Pharmacogenetics 12:197-208.

True WR, Xian H, Scherrer JF, Madden PA, Bucholz KK, Heath AC, Eisen SA, Lyons MJ, Goldberg J, Tsuang M (1999) Common genetic vulnerability for nicotine and alcohol dependence in men. Arch Gen Psychiatry 56:655-661.

Wada E, Wada K, Boulter J, Deneris E, Heinemann S, Patrick J, Swanson LW (1989) Distribution of alpha 2, alpha 3, alpha 4, and beta 2 neuronal nicotinic receptor subunit mRNAs in the central nervous system: a hybridization histochemical study in the rat. J Comp Neurol 284:314335.

Williams BM, Temburni MK, Levey MS, Bertrand S, Bertrand D, Jacob MH (1998) The long internal loop of the alpha 3 subunit targets $\mathrm{nAChRs}$ to subdomains within individual synapses on neurons in vivo. Nat Neurosci 1:557-562.

Wood SC, Forman SA, Miller KW (1991) Short chain and long chain alkanols have different sites of action on nicotinic acetylcholine receptor channels from Torpedo. Mol Pharmacol 39:332-338.

Zoli M, Lena C, Picciotto MR, Changeux JP (1998) Identification of four classes of brain nicotinic receptors using beta 2 mutant mice. J Neurosci 18:4461-4472.

Zuo Y, Aistrup GL, Marszalec W, Gillespie A, Chavez-Noriega LE, Yeh JZ, Narahashi T (2001) Dual action of n-alcohols on neuronal nicotinic acetylcholine receptors. Mol Pharmacol 60:700-711. 